\title{
Protein FAM49B
}

National Cancer Institute

\section{Source}

National Cancer Institute. Protein FAM49B. NCI Thesaurus. Code C112090.

Protein FAM49B (324 aa, $37 \mathrm{kDa}$ ) is encoded by the human FAM49B gene. This protein has an unknown function. 